\title{
MELLO, Marcelo Moura. 2012. Reminiscências dos quilombos: territórios da memória em uma comunidade negra rural. São Paulo: Editora Terceiro Nome. 267 pp.
}

Marcos Silva da Silveira O livro trata de um estudo a respeito de memórias de uma população quilombola

(UFPR) no Rio Grande do Sul. Nesta região, palco de vários processos históricos como as reduções jesuíticas e as guerras guaraníticas, no século XVIII, e a escravidão negra e a abolição, ao longo do século XIX, foi possível o surgimento de uma "brecha camponesa" negra. Com a grande imigração e a chegada dos europeus, porém, houve uma redefinição do lugar da população negra, com a perda de terras e a impossibilidade de um acesso pleno a direitos civis.

Cambará, comunidade negra rural no interior do Rio Grande do Sul, foi alvo de sucessivas expropriações ilícitas de suas terras. Este fato histórico, comum às demais regiões do país, resultou, no caso do Brasil meridional, na invisibilidade de sua população negra frente à maioria branca de origem europeia. Muitas das injustiças sofridas por esta população estão registradas em sua memória coletiva, que remete não apenas a um "tempo da escravidão", mas também a uma noção de "trabalhar como um escravo", ou de ser "tratado como um escravo", sem que estas percepções terminem em 1888. Essa memória coletiva, por sua vez, não se limita à terra como um território no sentido fundiário estrito, mas a um espaço de reprodução social com contornos próprios, que o autor se esforça por destacar e analisar.

A Constituição Federal de 1988, ao garantir direitos coletivos às comunidades quilombolas, é que teria permitido o surgimento de uma nova situação social um século após a abolição, com novas políticas de inclusão social que levaram ao reconhecimento de tais comunidades como legítimas. Desde 1996, a região sul do país passou a ser alvo de pesquisas dentro de iniciativas de levantamento das comunidades quilombolas. Nesta nova condição, o autor teve a oportunidade de visitar e pesquisar Cambará, inicialmente num projeto de extensão universitária, a partir de 2003.

A dissertação de mestrado que dá origem a este livro recebeu menção honrosa Campos 12(1): 135-137, 2011. no concurso ANPOCS de obras cientificas e teses universitárias em Ciências Sociais 
em 2009. Premiação seguramente merecida, devido à sua atualidade frente aos desafios da questão quilombola, em particular no Brasil meridional, e à sensibilidade do autor no tratamento de um objeto peculiar e de abordagem difícil.

A noção de "remanescentes de quilombos" é, primeiramente, analisada a partir de seu processo de ressemantização ao longo das últimas décadas. Com uma leitura muito bem atualizada com relação ao debate contemporâneo surgido após a Constituição de 1988, o livro discute a consolidação da especificidade da condição social de "camponês negro", progressivamente etnicizada frente ao Estado brasileiro por uma série de agentes sociais. A autoatribuição como critério legítimo de reconhecimento geraria uma série de estudos a respeito de comunidades quilombolas do Brasil, procurando expor a situação de pobreza etnicamente diferenciada dessas comunidades. Não são simplesmente comunidades pobres, mas pobres em função de serem compostas por negros livres, cuja negociação de sua liberdade tem sido profundamente problemática diante do Estado brasileiro desde a sua formação.

A opção pela memória coletiva como objeto de estudo privilegiou o estudo da produção de uma reconstrução do passado imposta pelas mudanças do presente. A identidade étnica - no caso a identidade quilombola - nesta comunidade negra do Rio Grande do Sul, passa, até certo ponto, por uma memória da escravidão. Passa mais, devido ao seu tempo histórico próprio, pelo processo de emancipação dos seus ancestrais a uma comunidade que ocupa, atualmente, um território descontínuo, na qual a imaginação e a lembrança permitem reconstituir uma identidade a partir de uma realidade por demais fragmentada. Poder apresentar relatos destas memórias, tentando ser fiel aos sentimentos coletivos que suscita, é o desafio bem sucedido dessa obra.

Não é possível falar dos quilombolas de Cambará sem contextualizar seu campo interétnico específico. Existem os morenos - já que negro, a principio, como em outros contextos brasileiros, tem conotação pejorativa; existem alemães, italianos e brasileiros, no caso os brancos nativos e os mestiços claros. Frente aos morenos, ou pretos, todos os demais são brancos. Os brancos exploram os morenos, e, com o surgimento das categorias quilombola e negro, essas relações de exploração começaram a ser questionadas. Na verdade, três localidades, Cambará, Palmas e Roseira, consideram-se uma só comunidade, ligadas por laços de parentesco e vizinhança, frente aos brancos, embora com uma série de distinções internas relevantes entre si. O campo interétnico é também um campo político, com laços e relações de reciprocidade entre brancos e pretos. Essas relações de reciprocidade são assimétricas e estruturam, historicamente, a vida social local, com suas tensões características. Brancos e pretos são vizinhos, os segundos trabalhando para os primeiros, às vezes até em terras que foram originalmente suas ou de seus ancestrais. Este quadro estruturado de injustiça é o que precisa ser revisto com as novas políticas de promoção de igualdade racial. Como implementá-las na prática - eis o grande desafio, para além da retórica igualitária que se faz presente no País, após a Constituição de 1988.

Este é um ponto bem explorado no livro. As políticas de promoção da igualdade racial constituem uma questão quilombola na região, procurando corrigir desigualdades históricas, com base em diversas referências ideológicas, inclusive a solidariedade cristã. O que se verifica, em campo, é um sistema interétnico centrado na exploração dos pretos pelos brancos. Fazer justiça, no caso, implica em reorganizar este sistema com reparações 
territoriais, econômicas e morais que colocarão em xeque a vida social local. Não basta apenas levantar a identidade negra desses quilombolas. Situá-los em seu contexto social especifico implica em questionar o contexto histórico no qual eles têm vivido.

Os antigos, no caso, os primeiros negros libertos a se fixarem na região, no inicio do século XIX, transformaram-se em um campesinato livre de negros forros, estabelecendo suas próprias redes de parentesco na região simultaneamente ao estabelecimento das redes sociais senhoriais - após a independência do Brasil, os movimentos separatistas gaúchos e a guerra do Paraguai. Relações de parentesco, de compadrio, relações de reciprocidade e de solidariedade vão se estabelecendo ao longo do século entre esses habitantes da região, constituindo a sua experiência comum que informa a identidade dos atuais quilombolas.

O final da escravidão e a libertação dos últimos escravos trariam, paradoxalmente, o inicio das injustiças presentes até hoje na região. Como já relatado para outras regiões do Brasil, o negro livre não era visto como um futuro cidadão, mas como um criminoso e uma ameaça em potencial. A criminalização dessa população negra irá se sobrepor, desde então, aos seus projetos de liberdade. Descritos, por um discurso oficial, como ladrões de gado, beberrões, "degenerados", serão alvo de uma ação estatal coercitiva, com a criação de milícias rurais, que, ao que tudo indica, foram criadas exclusivamente para controlá-los e mantê-los sob o domínio dos estancieiros. A criação de um espaço de liberdade possível não surge diretamente como resposta a esta ação coercitiva, conseguindo se realizar para além desta - todavia, com evidentes restrições, dentre elas a sistemática exclusão dos pretos, e das demarcações dos territórios por eles ocupados que oficializariam os limites municipais e distritais da região. Pretos invisíveis em territórios oficialmente "vazios", aos olhos do Estado, que fez livre uso dessas terras. O lugar no qual eles permaneceram visíveis continuava sendo dentro das fazendas, nas quais trabalhavam muito e desde muito novos, sujeitos a um regime de trabalho comparável ao do tempo da escravidão.

Expropriações de terra, exploração de mão de obra, violência e desrespeito constituem, assim, o próprio sistema de relações interétnicas que mantém a sociedade local, na qual os pretos se esforçam para manter e reproduzir suas redes de solidariedade autônomas. A memória local, portanto, retém e conta suas próprias histórias, silenciosas aos ouvidos daqueles que não os reconhecem como cidadãos. Trazer à tona essas memórias silenciadas, em um esforço de síntese considerável que acompanha todos os seis capítulos do livro, não implica simplesmente em reivindicar justiça para os pretos de Cambará. Significa chamar a atenção para o fato de que o reconhecimento e a proteção de um território quilombola passam, necessariamente, pelo reconhecimento e a credibilidade dos relatos e das histórias que constituem a identidade cultural desses negros. Eles precisam ser oficialmente ouvidos. Eles não têm direito às terras e aos investimentos governamentais em nome da suposta permanência de uma cultura africana original, mas em nome de um reconhecimento político da história de injustiças de que foram alvos nos últimos 100 anos, dentro de uma República brasileira em formação.

Marcos Silva da Silveira é professor do Departamento de Antropologia e do Programa de Pós-Graduação em Antropologia Social da Universidade Federal do Paraná 